\title{
The impact of modifying the ligands on hydrogen production electro-catalyzed by meso-tetra-p-X-phenylporphin cobalt complexes, $\operatorname{CoT}(\mathrm{X}) \mathrm{PP}$
}

\author{
Yin Liu ${ }^{a}$, Ling-Zhi Fu ${ }^{b}$, Le-Min Yang ${ }^{\text {a }}$, Xiao-Ping Liu ${ }^{\text {a }}$, Shu-Zhong Zhan ${ }^{\text {b*, }}$ \\ Chun-Lin $\mathrm{Ni}^{\mathrm{a} *}$ \\ ${ }^{a}$ College of Materials and Energy, Institute of Biomaterial, South China Agricultural \\ University, Guangzhou 510642, P. R. China. \\ ${ }^{\mathrm{b}}$ College of Chemistry and Chemical Engineering, South China University of \\ Technology, Guangzhou 510640, China.
}

Two molecular electro-catalysts based on cobalt complexes CoT(X)PP $1(X=C l)$ and $2(\mathrm{X}=\mathrm{OMe})$ are formed by the reaction of meso-tetra- $p$-X-phenylporphin, $\mathrm{H}_{2} \mathrm{~T}(\mathrm{X}) \mathrm{PP}$ with cobalt compound for electrolytic proton or water reduction. 1 electrocatalyzes hydrogen evolution from acetic acid with a turnover frequency (TOF) of 85.51 moles of hydrogen per mole of catalyst per hour at an overpotential (OP) of $941.6 \mathrm{mV}$ (in DMF), and from aqueous buffer solution ( $\mathrm{pH} 7.0$ ) with a TOF of 632.9 moles of hydrogen per mole of catalyst per hour at an OP of $837.6 \mathrm{mV}$. And 2 electrocatalyzes hydrogen evolution from acetic acid with a TOF of 48.70 moles of hydrogen per mole of catalyst per hour at an OP of $941.6 \mathrm{mV}$ (in DMF), and from aqueous buffer solution ( $\mathrm{pH} 7.0$ ) with a TOF of 120.1 moles of hydrogen per mole of catalyst per hour at an $\mathrm{OP}$ of $837.6 \mathrm{mV}$. These results indicate that the electronic properties of the ligands play vital roles in determining the catalytic activities of the cobalt complexes, and are consistent with an evident increase in the catalytic activity when 
electron-withdrawing groups are present at phenylporphin, and $m e s o$-tetra-p-chloro-phenylporphin constitutes the better active catalyst.

Keywords: Porphin-cobalt complexes; molecular electrocatalysts; water reduction; hydrogen evolution.

\footnotetext{
* Corresponding authors. E-mail addresses: shzhzhan@scut.edu.cn (S.-Z. Zhan) and niclchem@scau.edu.cn
}

\section{Introduction}

Hydrogen is one of the most ideal energy carriers and a possible alternative to fossil fuels in the future, because of its numerous advantages such as recyclability and pollution-free use [1]. Water splitting is one of the most attractive technologies for sustainable energy production [2]. Yet, one of the key challenges in water splitting is the development of efficient catalysts for water reduction reactions with low overpotentials, good stability, and high turnover rates $[3,4]$. Therefore, a great deal of research efforts have been devoted to the development of effective catalysts based on earth-abundant metals, and molecular complexes of nickel [5], cobalt [6-8], molybdenum [9] and copper [10-12] for the reduction of water to form $\mathrm{H}_{2}$. Nevertheless, despite much progress, major improvements in several areas, including lowering overpotentials, increasing catalyst durability, and using earth-abundant elements, are needed before efficient electro-catalytic water splitting can be realized. As we know, the donor type and electronic properties of the ligands play vital roles in determining the structure and reactivity of the corresponding metal complexes $[13,14]$. 
Within this context, we have been studying tetradentate ligands, such as meso-tetra-p-X-phenylporphin $\mathrm{H}_{2} \mathrm{~T}(\mathrm{X}) \mathrm{PP}(\mathrm{X}=\mathrm{Cl}, \mathrm{OMe})$, planar ligands and their corresponding cobalt complexes for catalytic application. In this paper, we report electrocatalytic properties for hydrogen generation of two cobalt(II) complexes $\mathrm{CoT}(\mathrm{X}) \mathrm{PP} \mathbf{1}(\mathrm{X}=\mathrm{Cl})$ and $\mathbf{2}(\mathrm{X}=\mathrm{OMe})$, as well as the effect of tetradentate ligand modifications on the catalytic efficiency of these two cobalt(II) complexes.

\section{Experimental}

$\mathrm{H}_{2} \mathrm{~T}(\mathrm{X}) \mathrm{PP}$ and $\mathrm{CoT}(\mathrm{X}) \mathrm{PP}$ were prepared according to the procedures in the literatures $[15,16]$. Cyclic voltammograms (CVs) were obtained on a CHI-660E electrochemical analyzer under $\mathrm{N}_{2}$ using a three-electrode cell in which a glassy carbon electrode was the working electrode, a saturated $\mathrm{Ag} / \mathrm{AgCl}$ electrode was the reference electrode, and platinum wire was the auxiliary electrode. In organic media, the ferrocene/ferrocenium (1+) couple was used as an internal standard, and $0.10 \mathrm{M}$ $\left[(\mathrm{n}-\mathrm{Bu})_{4} \mathrm{~N}\right] \mathrm{ClO}_{4}$ was used as the supporting electrolyte. Controlled-potential electrolysis (CPE) in aqueous media was conducted using an air-tight glass double compartment cell separated by a glass frit. The working compartment was fitted with a glassy carbon plate and an $\mathrm{Ag} / \mathrm{AgCl}$ reference electrode. The auxiliary compartment was fitted with a Pt gauze electrode. The working compartment was filled with $50 \mathrm{~mL}$ of $0.25 \mathrm{M}$ buffer, while the auxiliary compartment was filled with $35 \mathrm{~mL}$ phosphate buffer solution. After addition of cobalt complexes, CVs were recorded. After electrolysis, a $0.50 \mathrm{~mL}$ aliquot of the headspace was removed and replaced with 0.50 
$\mathrm{mL}$ of $\mathrm{CH}_{4}$. The headspace sample was injected into the gas chromatograph (GC). GC experiments were carried out with an Agilent Technologies 7890A gas chromatography instrument.

\section{Results and discussion}

\subsection{Electrochemical studies}

To explore the electrochemical properties of $\mathbf{1}$ and $\mathbf{2}, \mathrm{CVs}$ were conducted in DMF with $0.10 \mathrm{M}\left[(\mathrm{n}-\mathrm{Bu})_{4} \mathrm{~N}\right] \mathrm{ClO}_{4}$ as the supporting electrolyte. As observed in Fig. 1, complexes 1 and $\mathbf{2}$ both exhibit two redox waves and followed the order $\mathbf{1}(-0.76$ and $-1.86 \mathrm{~V}$ versus $\left.\mathrm{Ag} / \mathrm{AgNO}_{3}\right) \rightarrow \mathbf{2}\left(-0.92\right.$ and $-1.39 \mathrm{~V}$ versus $\left.\mathrm{Ag} / \mathrm{AgNO}_{3}\right)$, respectively. As shown in Fig. 1a, the CV of $3.17 \mathrm{mM}$ complex 1 shows two reversible peaks at $-0.76 \mathrm{~V}$ and $-1.86 \mathrm{~V}$ versus $\mathrm{Ag} / \mathrm{AgNO}_{3}$, respectively. For comparison, $\mathrm{CV}$ of $\mathrm{H}_{2} \mathrm{~T}(\mathrm{Cl}) \mathrm{PP}$ was measured in a similar condition (Fig. 1b). The first reduction wave of 1 at $-0.76 \mathrm{~V}$, being close to the first reduction of the free ligand, is assigned to $\mathrm{H}_{2} \mathrm{~T}(\mathrm{Cl}) \mathrm{PP}$. The second redox peak can be assigned to the $\mathrm{Co}^{\mathrm{II}} / \mathrm{Co}^{\mathrm{I}}$ couple. From Fig. 1c, complex 2 also shows two reversible peaks at $-0.92 \mathrm{~V}$ and $-1.39 \mathrm{~V}$ versus $\mathrm{Ag} / \mathrm{AgNO}_{3}$, respectively. $\mathrm{H}_{2} \mathrm{~T}(\mathrm{OMe}) \mathrm{PP}$ exhibits one reversible peak at $-1.12 \mathrm{~V}$ versus $\mathrm{Ag} / \mathrm{AgNO}_{3}$ (Fig. 1d). The first reduction wave of 2 at $-0.92 \mathrm{~V}$, being close to the first reduction of $\mathrm{H}_{2} \mathrm{~T}(\mathrm{OMe}) \mathrm{PP}$, is assigned to the $\mathrm{H}_{2} \mathrm{~T}(\mathrm{OMe}) \mathrm{PP}$. The second redox peak at $-1.39 \mathrm{~V}$ versus $\mathrm{Ag} / \mathrm{AgNO}_{3}$ can be assigned to the $\mathrm{Co}{ }^{\mathrm{II}} / \mathrm{Co}^{\mathrm{I}}$ couple. Note, the potential of $\mathrm{Co}^{\mathrm{II}} / \mathrm{Co}^{\mathrm{I}}$ is shifted by $470 \mathrm{mV}$ as a result of substitution of a methoxyl group on the ligand by the more electron withdrawing chloride group. 


\subsection{Catalytic hydrogen evolution from acetic acid in $D M F$}

As depicted in Fig. 2a, with the addition of varied amounts of acetic acid (from 0.0 to $4.08 \mathrm{mM}$ ), apparent voltammetric currents emerge at $-1.90 \mathrm{~V}$ and increase markedly with increasing proton concentration. The result indicates that hydrogen evolution electrocatalyzed by 1 requires the reduction of $\mathrm{Co}(\mathrm{II})$ to $\mathrm{Co}(\mathrm{I})$ and protonation. Interestingly, with the acetic acid concentration increased from 0.0 to $4.08 \mathrm{mM}$ (Fig. 2a), the onset of the catalytic wave remains almost constant at ca. $-1.70 \mathrm{~V}$ versus $\mathrm{Ag} / \mathrm{AgNO}_{3}$. Based on the above observations, only the $\mathrm{Co} / \mathrm{Co}^{\mathrm{II}}$ couple is involved in proton reduction.

On the basis of literature precedents [17-19] and above analyses, a possible catalytic cycle for the generation of hydrogen from acid mediated by $\mathbf{1}$ is depicted in Scheme 1. One-electron reduction of $\left[\mathrm{Co}^{\mathrm{II}} \mathrm{T}(\mathrm{Cl}) \mathrm{PP}\right] \mathbf{1}$ produces a putative $\left[\mathrm{Co}^{\mathrm{I}} \mathrm{T}(\mathrm{Cl}) \mathrm{PP}\right]^{-}$species. Addition of proton yields the $\mathrm{Co}^{\mathrm{III}}-\mathrm{H}$ species, a high reactive intermediate. Further reduction of the $\mathrm{Cu}^{\mathrm{III}}-\mathrm{H}$ species affords $\mathrm{H}_{2}$, and regenerates the starting complex 1 . 
Scheme 1. The possible catalytic mechanism for proton reduction by porphin cobalt complexes

Compared to that of complex $\mathbf{1}$, change of catalytic current for complex 2 occurred at the couple of $\mathrm{Co} / \mathrm{II} / \mathrm{Co}^{\mathrm{I}}\left(-1.44 \mathrm{~V}\right.$ versus $\left.\mathrm{Ag} / \mathrm{AgNO}_{3}\right)$, and the peak current of $\mathrm{Co}^{\mathrm{II}} / \mathrm{Co}^{\mathrm{I}}$ also increased markedly with increasing proton concentration (acetic acid concentration increased from 0.0 to $2.33 \mathrm{mM}$ ) (Fig. 2b), indicating that complexes 1 and 2 both afford proton reduction from acetic acid. Different from complex 1, with the acetic acid concentration increased from 0.0 to $2.33 \mathrm{mM}$ (Fig. 2b), the onset of the catalytic wave moves positive for about $290 \mathrm{mV}$ compared to that in the absence of acetic acid.

In order to further assess the catalytic activities of complexes $\mathbf{1}$ and $\mathbf{2}$, bulk 
electrolysis were conducted in DMF solutions with acetic acid at variable applied potential using a glassy carbon plate electrode in a double-compartment cell. Figs. 3a-b show the total charges of bulk electrolysis of complexes $\mathbf{1}$ and $\mathbf{2}$ in the presence of acid. When the applied potential is $-1.45 \mathrm{~V}$ versus $\mathrm{Ag} / \mathrm{AgNO}_{3}$, the maximum charges reaches $81 \mathrm{mC}$ and $51 \mathrm{mC}$, respectively, during $2 \mathrm{~min}$ of electrolysis. And a CPE experiment under the same potential without complex $\mathbf{1}$ or complex $\mathbf{2}$ gives a charge of only $12 \mathrm{mC}$ (Fig. 3c), showing that these two complexes do indeed serve as effective hydrogen producers under such conditions. Assuming every catalyst molecule is distributed only on the electrode surface and every electron is used for the reduction of protons, according to Equations (1) [20] and (2) [21], complexes 1 and 2 afford 85.51 and 48.7 moles of hydrogen per mole of catalyst per hour at an OP of 941.6 $\mathrm{mV}$, respectively (Eqs. S1-S2). Remarkably, complex $\mathbf{1}$ is more active than that of complex 2, which is consistent with an evident increase in the catalytic activity when electron-withdrawing group, such as chloride is present at phenylporphin, and meso-tetra-p-chloro-phenylporphin constitutes the better active catalyst [22]. And the cobalt complexes with more positive $\mathrm{Co}^{\mathrm{II} / \mathrm{I}}$ redox potentials show lower activity for hydrogen generation.

$$
\mathrm{TOF}=\Delta C /\left(\mathrm{F}^{*} n_{1} * n_{2} * t\right)
$$

$$
\begin{aligned}
\text { Overpotential } & =\text { Applied potential }-\mathrm{E}^{\odot}{ }_{\mathrm{HA}} \\
& =\text { Applied potential }-\left(\mathrm{E}^{\odot}{ }_{\mathrm{H}}{ }^{+}-(2.303 R T / F) \mathrm{p} K_{a \mathrm{HA}}\right)
\end{aligned}
$$

Where, $\Delta C$ is the charge from the catalyst solution during CPE minus the charge from solution without catalyst during $\mathrm{CPE} ; \mathrm{F}$ is Faraday's constant, $n_{1}$ is the number 
of moles of electrons required to generate one mole of $\mathrm{H}_{2}, n_{2}$ is the number of moles of catalyst in solution, and $\mathrm{t}$ is the duration of electrolysis.

\subsection{Catalytic hydrogen evolution from aqueous buffer}

We further explored the electrochemical behavior of complex $\mathbf{1}$ in buffered aqueous solutions, where $\mathrm{pH}=3.5-7.0$ which is the range associated with catalytic water reduction. And Fig. $4 \mathrm{a}$ exhibits a systematic increase in $i_{\text {cat }}$ with decreasing $\mathrm{pH}$ from 7.0 to 3.5. As shown in Fig. 4b, in the absence of complex 1, a catalytic current is not apparent until a potential of $-1.50 \mathrm{~V}$ versus $\mathrm{Ag} / \mathrm{AgCl}$ is attained. Upon addition of complex 1, the onset of catalytic current is observed at about $-1.30 \mathrm{~V}$ versus $\mathrm{Ag} / \mathrm{AgCl}$, showing that addition of complex 1 can reduce the potential, and the current strength increases significantly with increasing concentrations of complex $\mathbf{1}$ from 10.50 to $80.60 \mu \mathrm{M}$. From Fig. $4 \mathrm{a}$, the onset of this catalytic current is clearly influenced by the solution $\mathrm{pH}$, the applied potential declines with increasing $\mathrm{pH}$, evidencing the involvement of a proton in the initial stage of electrochemical catalysis.

As shown in Fig. 5a, in the absence of complex 2, a catalytic current is not apparent until a potential of $-1.50 \mathrm{~V}$ versus $\mathrm{Ag} / \mathrm{AgCl}$ is attained. With addition of complex 2 , the onset of catalytic current is observed at about $-0.87 \mathrm{~V}$ versus $\mathrm{Ag} / \mathrm{AgCl}$, and the current strength increased significantly with increasing concentrations of complex 2 from 0.39 to $1.36 \mu \mathrm{M}$ (Fig. 5a). From Fig. 5b, 2 shows a pH-dependent peak at $-1.62 \mathrm{~V}$ versus $\mathrm{Ag} / \mathrm{AgCl}$, which is responsible for catalytic water reduction, 
and the applied potential declines with increasing $\mathrm{pH}$ (Fig. 5b).

To further test the electro-catalytic activity of complex $\mathbf{1}$ in aqueous media, bulk electrolysis was measured in an aqueous solution of $1(3.09 \mu \mathrm{M})$ with $0.25 \mathrm{M}$ buffer solution ( $\mathrm{pH}$ 7.0) at variable potential using a glassy carbon electrode in a double-compartment cell. From Fig. 6a, when the applied potential is $-1.45 \mathrm{~V}$ versus $\mathrm{Ag} / \mathrm{AgCl}$, the maximum charge is only $33 \mathrm{mC}$ for $2 \mathrm{~min}$ of electrolysis in the absence of complex 1. Under the same conditions, the charge reaches $541 \mathrm{mC}$ during $2 \mathrm{~min}$ of electrolysis in the presence of $\mathbf{1}$ (Fig. 6b), accompanying a large amount of gas bubble appeared, which is confirmed as $\mathrm{H}_{2}$ by gas chromatography. According to Fig. S1a, $\sim 2.8 \mathrm{~mL}$ of $\mathrm{H}_{2}$ is produced over an electrolysis period of $1 \mathrm{~h}$ with a Faradaic efficiency of $91.12 \%$ for $\mathrm{H}_{2}$ (Fig. S1b). According to Equations (1) and (3) [23], we calculate the TOF for the catalyst as reaching a maximum of 632.9 moles of hydrogen per mole of catalyst per hour at an overpotential of $836.7 \mathrm{mV}$ (Eq. S3), where

Overpotential $=$ Applied potential- $\mathrm{E}(\mathrm{pH})=$ Applied potential- $(-0.059 \mathrm{pH})$

To the best of our knowledge, this value is higher than that of some other molecular catalysts reported in the literature for electrochemical hydrogen production from neutral water. For instance, a dinickel complex that exhibits a TOF of 160 moles of $\mathrm{H}_{2}$ per mole of catalyst per hour at an overpotential of $820 \mathrm{mV}$ [24] and a cobalt complex displaying a turnover number of 5 molesof $\mathrm{H}_{2}$ per mole of catalyst with a turnover number of 0.4 moles of $\mathrm{H}_{2}$ per mole of catalyst per hour at an $\mathrm{OP}$ of $390 \mathrm{mV}$ [25]. This indicates that complex $\mathbf{1}$ is a highly active catalyst, probably because of its unique structure: the planar ligand, $\mathrm{T}(\mathrm{Cl}) \mathrm{PP}^{2-}$ can stabilize low oxidation state of 
cobalt. This observation suggests that the presence of the ligand is the key structural feature for eliciting proton or water reduction catalysis.

According to Fig. 6c, when the applied potential was $-1.45 \mathrm{~V}$ versus $\mathrm{Ag} / \mathrm{AgCl}$, the maximum charge reaches $131 \mathrm{mC}$ during $2 \mathrm{~min}$ of electrolysis in the presence of 2 , accompanied by evolution of a gas, which is confirmed as $\mathrm{H}_{2}$ by gas chromatography. From Fig. S12a, $\sim 0.80 \mathrm{~mL}$ of $\mathrm{H}_{2}$ is produced over an electrolysis period of $1 \mathrm{~h}$ with a Faradaic efficiency of $92.3 \%$ for $\mathrm{H}_{2}$ (Fig. S2b). From Equations (1) and (3), complex 1 affords a TOF of 120.1 moles of hydrogen per mole of catalyst per hour at an OP of $837.6 \mathrm{mV}$ (Eq. S4). Similar to that in organic media, complex 1 also shows higher efficiency for hydrogen production than that of complex 2. From a $72 \mathrm{~h}$ CPE of a 0.25 $\mathrm{M}$ buffer solution ( $\mathrm{pH} 7.0$ ) in the presence of complex 1 or 2 under $-1.40 \mathrm{~V}$ versus $\mathrm{Ag} / \mathrm{AgCl}$, we also can found that catalyst $\mathbf{1}$ is a more active species than $\mathbf{2}$. As shown in Fig. S3a, a total of $3445 \mathrm{C}$ is accumulated during the electrolysis catalyzed by complex $\mathbf{1}$, and in the presence of complex 2 , only $868 \mathrm{C}$ is passed during a $72 \mathrm{~h}$ electrolysis (Fig. S3b).

As we know, it is not easy to compare the catalytic efficiency between different electrocatalytic systems in term of TOF, due to possible differences in the experimental conditions conducted. Under the same conditions, a comparison of the hydrogen evolving activity obtained with electrocatalytic system reported in the literature based on cobalt porphyrin [26], shows that $\mathbf{1}$ is more active than the tetrakis(p-sulfonatophenyl)porphyrin cobalt complex, Co(TPPS) reported by Beyene giving $1.83 \mathrm{~s}^{-1}$ at an applied potential of $-1.29 \mathrm{~V}$ versus SHE in neutral phosphate buffer 
solution (Table 1).

Table 1 Catalytic data by porphyrin cobalt complexes from aqueous buffer

\begin{tabular}{|c|c|c|c|}
\hline Complexes & Co(TPPS) & $\mathbf{1}$ & $\mathbf{2}$ \\
\hline TOF $\left(\mathrm{s}^{-1}\right)$ & 1.83 & 5.68 & 1.17 \\
\hline Applied potential $(\mathrm{V} v \mathrm{SHE})$ & -1.29 & -1.29 & -1.29 \\
\hline
\end{tabular}

CoTPPS: (p-sulfonatophenyl)porphyrin cobalt complex [26].

\section{Summary}

In this paper, we have described two electrocatalysts based on meso-tetra- $p$-X-phenylporphin cobalt complexes. The cobalt complexes with more positive $\mathrm{Co}^{\mathrm{II} / \mathrm{I}}$ redox potentials show lower activity for hydrogen generation. And the results are consistent with an evident increase in the catalytic activity when electron-withdrawing groups are present at the phenol para-position of the ligand. Our ongoing efforts are focused on modifying phenylporphin ligand to give related water-soluble complexes for further functional studies, with an emphasis on chemistry relevant to sustainable energy cycles.

\section{Acknowledgements}

This work was supported by the National Science Foundation of China (No. 20971045, 21271073).

\section{References}

[1] M. G. Walter, E. L. Warren, J. R. McKone, S. W. Boettcher, Q. X. Mi, E. A. 
Santori, N. S. Lewis, Chem. Rev. 110, 6446 - 6473 (2010).

[2] H. M. Chen, C. K. Chen, R. S. Liu, L. Zhang, J. J. Zhang, D. P. Wilkinson, Chem. Soc. Rev. 41, 5654-5671 (2012)

[3] R. Eisenberg, H. B. Gray, Inorg. Chem. 47, 1697-1699 (2008).

[4] J. Barber, Chem. Soc. Rev. 38, 185-196 (2009).

[5] J. P. Cao, T. Fang, L. Z. Fu, L. L. Zhou, S. Z. Zhan, Int. J. Hydrogen Energy 39, 10980-10986 (2014).

[6] C. C. L. McCrory, C. Uyeda, J. C. Peters, J. Am. Chem. Soc. 134, 3164-3170 (2012).

[7] W. M. Singh, T. Baine, S. Kudo, S. Tian, X. A. N. Ma, H. Zhou, N. J. DeYonker, T. C. Pham, J. C. Bollinger, D. L. Baker, B. Yan, C. E. Webster, X. Zhao, Angew. Chem. Int. Ed. 51, 5941-5944 (2012).

[8] L. Tong, R. Zong, R. P. Thummel, J. Am. Chem. Soc. 136, 4881-4884 (2014).

[9] H. I. Karunadasa, C. J. Chang, J. R. Long, Nature 464, 1329-1333 (2010).

[10] J. P. Cao, T. Fang, L. Z. Fu, L. L. Zhou, S. Z. Zhan, Int. J. Hydrogen Energy 39, 13972-13978 (2014).

[11] L. L. Zhou, T. Fang, J. P. Cao, Z. Zhu, X. Su, S. Z. Zhan, J. Power Sources 273, 298-304 (2015).

[12] T. Fang, L. Z. Fu, L. L. Zhou, S. Z. Zhan, Electrochimica Acta 161, 388-394 (2015).

[13] J. L. Fillol, Z. Codolà, I. Garcia-Bosch, L. Gómez, J. J. Pla, M. Costas, Nature Chem. 3, 807-813 (2011). 
[14] X. Hu, B. S. Brunschwig, J. C. Peter, J. Am. Chem. Soc. 129, 8988-8998 (2007).

[15] A. D. Adler, F. R. Longo, J. D. Finarelli, J. Goldmacher, J. Assour, L. Korsakoff, J. Org. Chem. 32, 476-476 (1967).

[16] A. D. Adler, F. R. Longo, F. Kampas, J. Inorg. Nucl. Chem. 32, 2443-2453 (1970).

[17] J. T. Muckermann, E. Fujita, Chem. Commun. 47, 12456-12458 (2011).

[18] J. Xie, Q. Zhou, C. Li, W. Wang, Y. Hou, B. Zhang, X. Wang, Chem. Commun. 50, 6520-6522 (2014).

[19] A. E. King, Y. Surendranath, N. A. Piro, J. P. Bigi, J. R. Long, C. J. Chang, Chem. Sci. 4, 1578-1587 (2013).

[20] L. Z. Fu, L. L. Zhou, L. Z. Tang, Y. X. Zhang, S. Z. Zhan, J. Power Sources 280, 453-458 (2015).

[21] G. A. N. Felton, R. S. Glass, D. L. Lichtenberger, D. H. Evans, Inorg. Chem. 45, 9181-9184 (2006).

[22] Z. Codol, I. Garcia-Bosch, F. Acuna-Pares, I. Prat, J. M. Luis, M. Costas, J. Lloret-Fillol, Chem. Eur. J. 19, 8042-8047 (2013).

[23] H. I. Karunadasa, C. J. Chang, J. R. Long, Nature 464, 1329-1333 (2010).

[24] J. Collin, A. Jouaiti, J. P. Sauvage, Inorg. Chem. 27, 1986-1990 (1988).

[25] P. V. Bernhardt, L. A. Jones, Inorg. Chem. 38, 5086-5090 (1999).

[26] B. B. Beyene, S. B. Manea, C. H. Hung, Chem. Commun. 51, 15067-15070 (2015). 

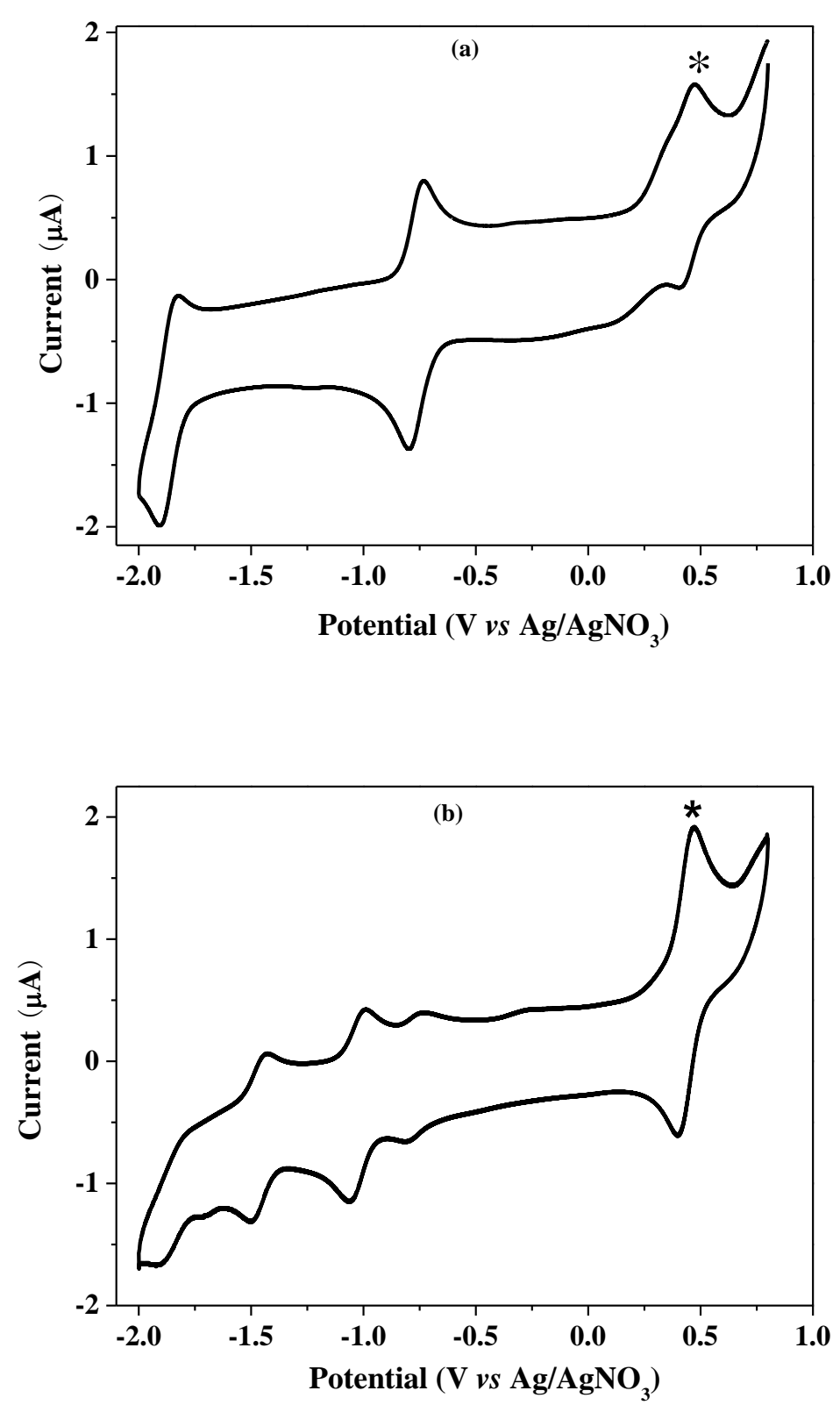

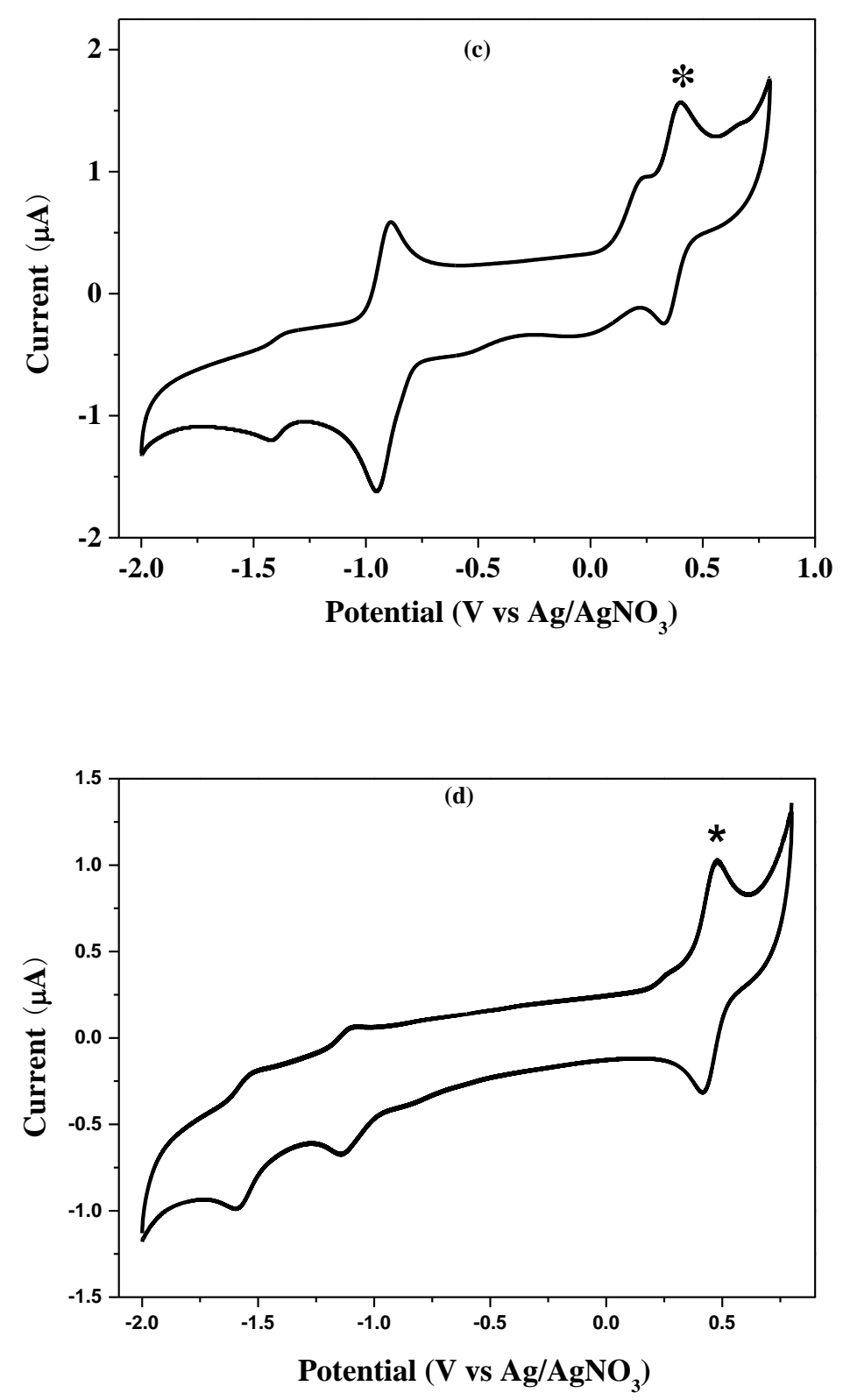

Fig. 1. (a) Cyclic voltammogram (CV) of $0.86 \mathrm{mM}$ complex 1 in DMF. (b) $\mathrm{CV}$ of $\mathrm{H}_{2} \mathrm{~T}(\mathrm{Cl}) \mathrm{PP}(31.5 \mu \mathrm{M})$ in DMF. (c) $\mathrm{CV}$ of $0.86 \mathrm{mM}$ complex 2 in DMF. (d) $\mathrm{CV}$ of $\mathrm{H}_{2} \mathrm{~T}(\mathrm{OMe}) \mathrm{PP}(23 \mu \mathrm{M})$ in DMF. Conditions: $0.10 \mathrm{M}\left[\mathrm{n}-\mathrm{Bu}_{4} \mathrm{~N}\right] \mathrm{ClO}_{4}$ as supporting electrolyte, glassy carbon working electrode (1 mm diameter), Pt counter electrode, $\mathrm{Ag} / \mathrm{AgNO}_{3}$ reference electrode, scan rate $100 \mathrm{mV} / \mathrm{s}$, Ferrocene internal standard (*). 

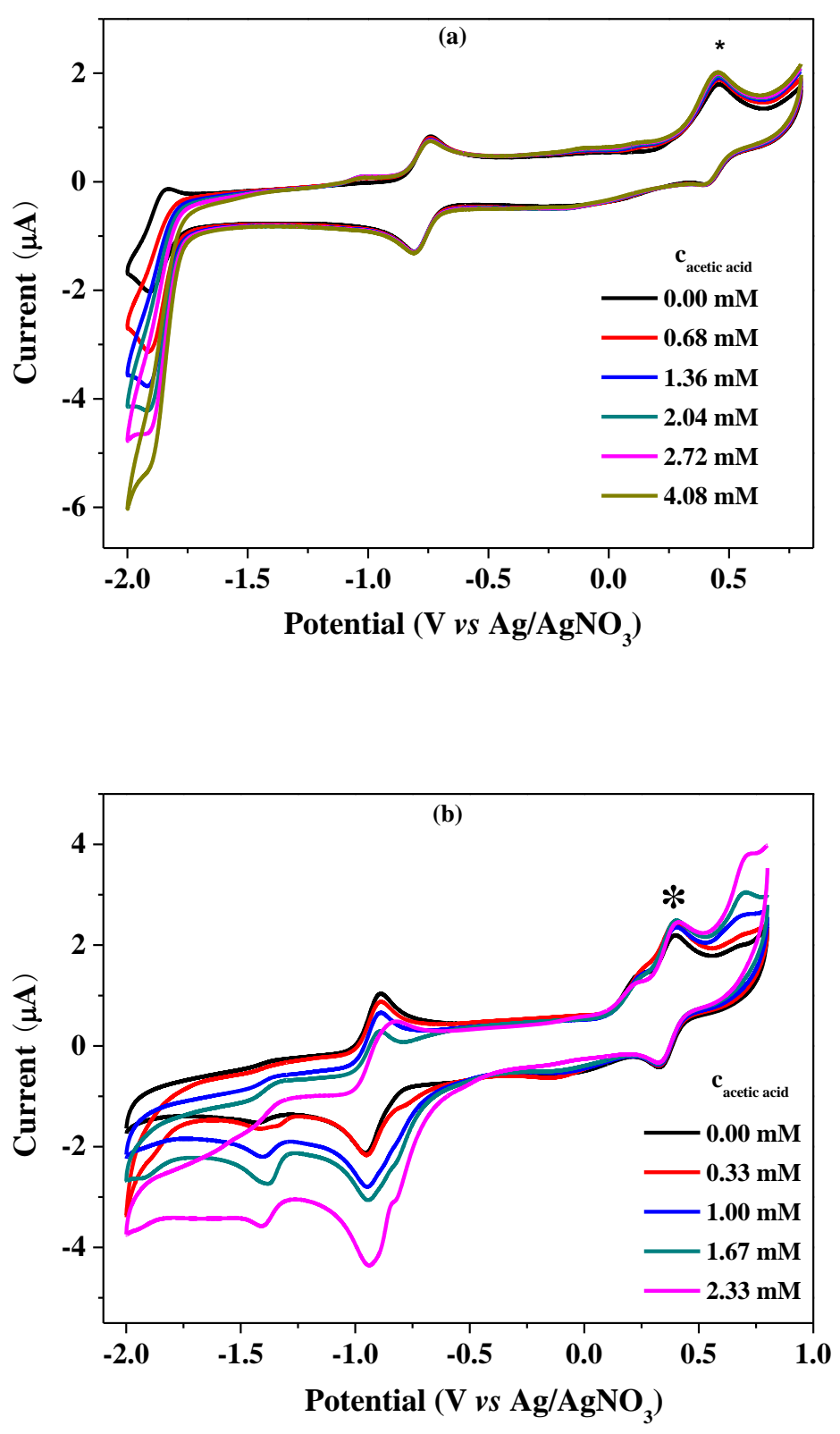

Fig. 2. (a) CVs of a $0.25 \mathrm{mM}$ solution of complex 1, with varying concentration of acetic acid in DMF. (b) CVs of a $0.43 \mathrm{mM}$ solution of complex 2, with varying concentration of acetic acid in DMF. Conditions: $0.10 \mathrm{M}\left[\mathrm{n}-\mathrm{Bu}_{4} \mathrm{~N}\right] \mathrm{ClO}_{4}$ as supporting electrolyte, scan rate: $100 \mathrm{mV} / \mathrm{s}$, glassy carbon working electrode (1 mm diameter), $\mathrm{Pt}$ counter electrode, $\mathrm{Ag} / \mathrm{AgNO}_{3}$ reference electrode, $\mathrm{Fc}$ internal standard (*). 

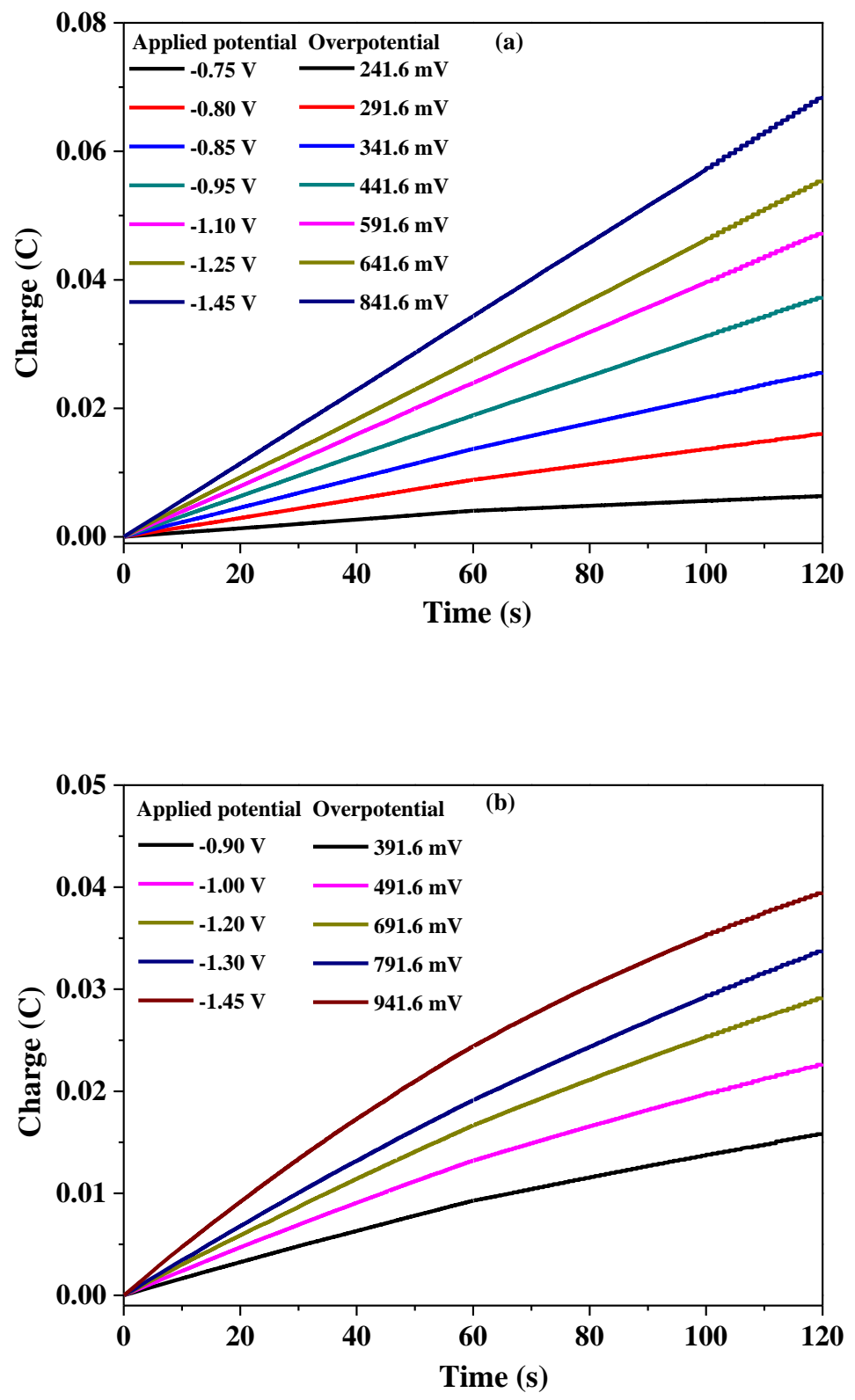


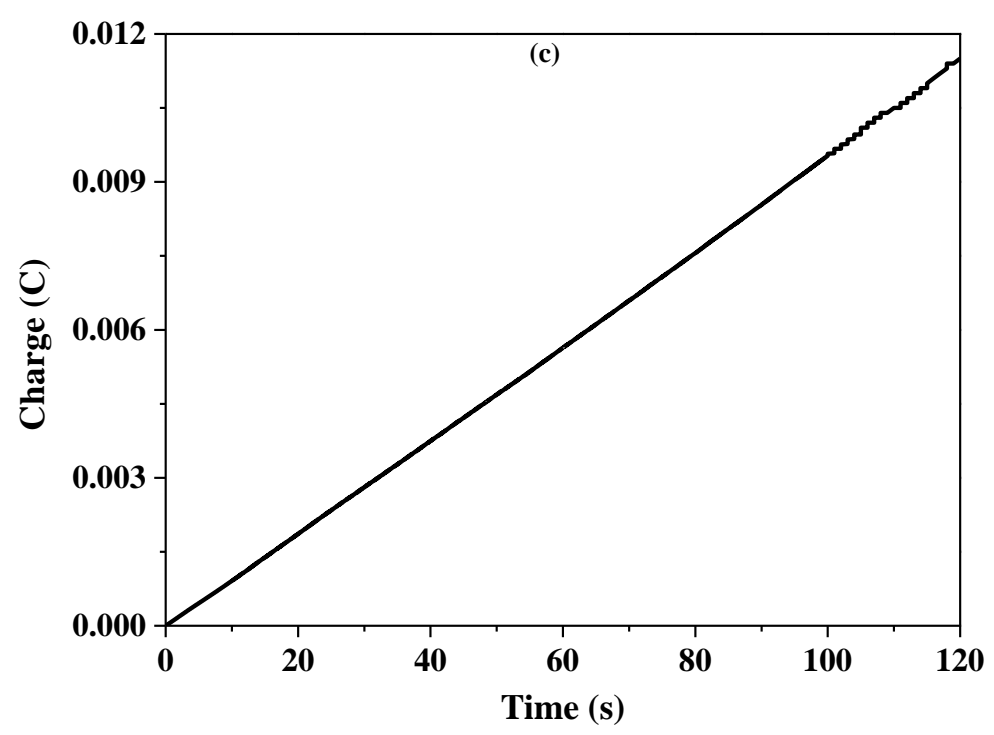

Fig. 3. (a) Charge buildup versus time from electrolysis of $4.0 \mathrm{mM}$ acetic acid with $3.09 \mu \mathrm{M}$ complex 1 in DMF. All data have been deducted blank. (b) Charge buildup versus time from electrolysis of $4.0 \mathrm{mM}$ acetic acid with $2.28 \mu \mathrm{M}$ complex 2 in DMF. All data have been deducted blank. (c) Charge buildup versus time from electrolysis of $0.10 \mathrm{M}\left[\mathrm{n}-\mathrm{Bu}_{4} \mathrm{~N}\right] \mathrm{ClO}_{4}$ in DMF. 

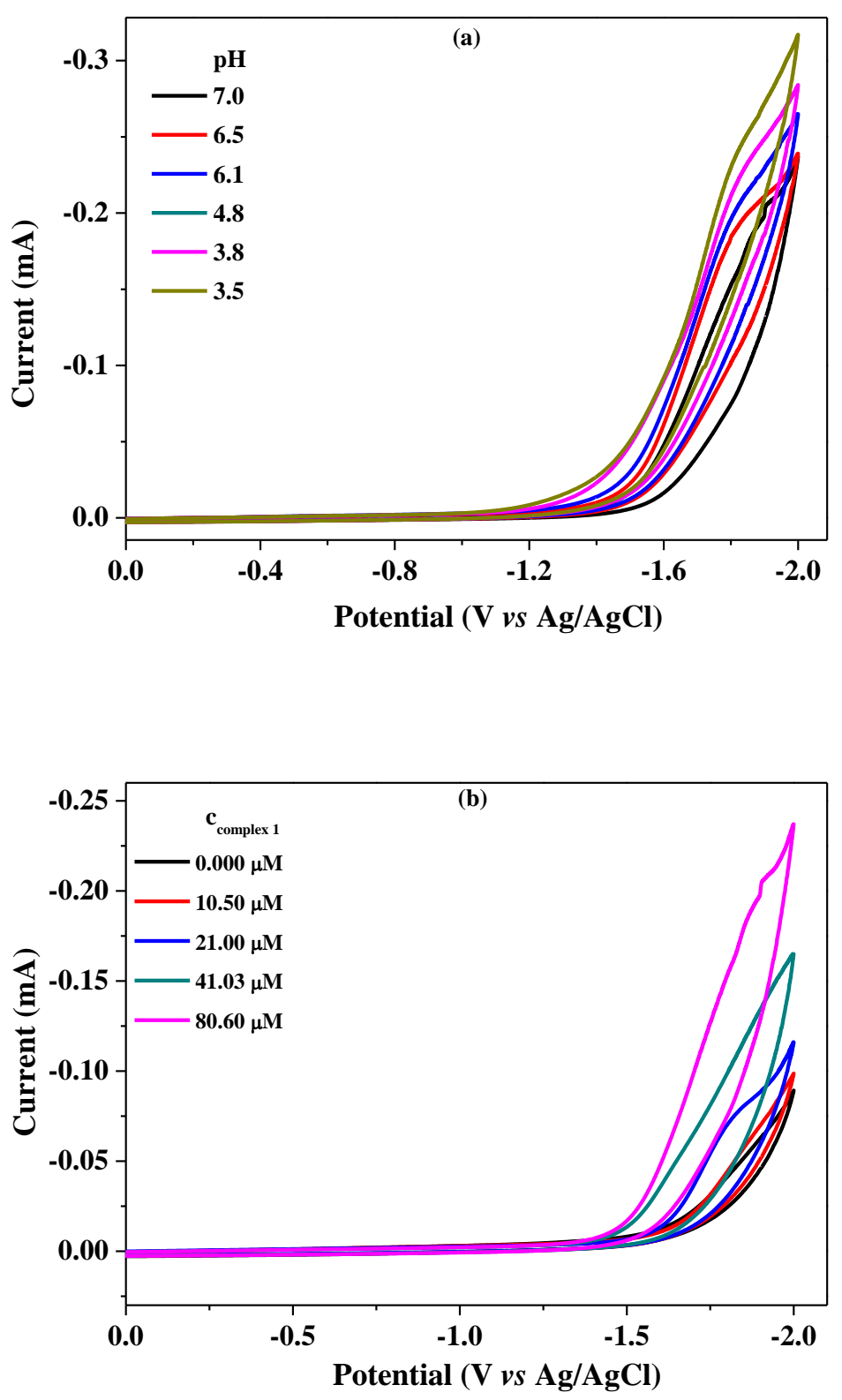

Fig. 4. (a) CVs of $0.081 \mathrm{mM}$ complex 1, showing the variation in catalytic current with $\mathrm{pH}$ (scan rate: $100 \mathrm{mV} / \mathrm{s}$ ). (b) Cyclic voltammograms of complex $\mathbf{I}$ in different concentration. Conditions: $0.25 \mathrm{M}$ phosphate buffered solution at $\mathrm{pH} 7.0$, glassy carbon working electrode (1 mm diameter), $\mathrm{Pt}$ wire counter electrode, $\mathrm{Ag} / \mathrm{AgCl}$ reference electrode. 

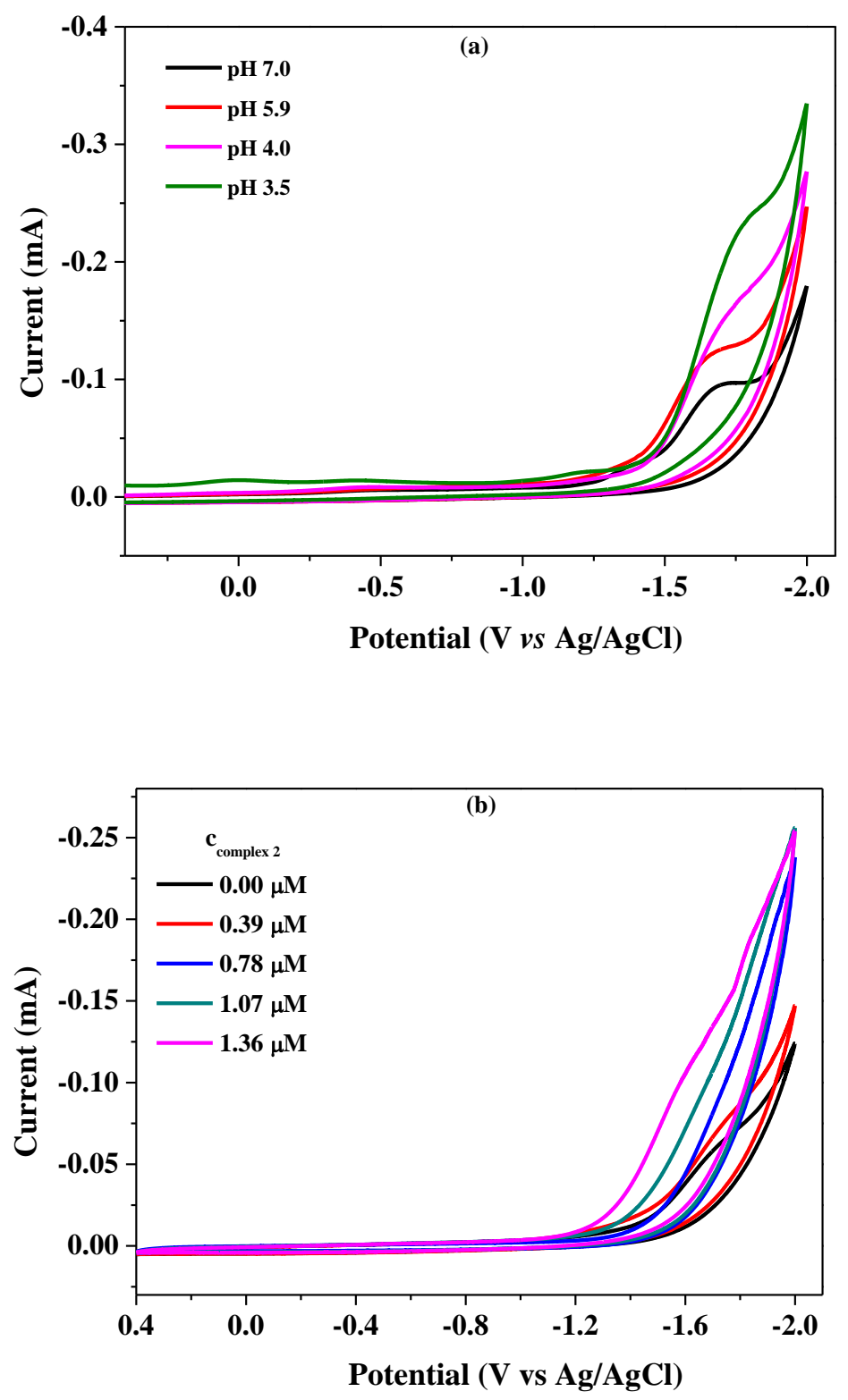

Fig. 5. (a) CVs of $1.36 \mu \mathrm{M}$ complex 2 , showing the variation in catalytic current with $\mathrm{pH}$ (scan rate: $100 \mathrm{mV} / \mathrm{s}$ ). (b) Cyclic voltammogram of complex 2 in different concentration. Conditions: $0.25 \mathrm{M}$ phosphate buffered solution at $\mathrm{pH} 7.0$, glassy carbon working electrode ( $1 \mathrm{~mm}$ diameter), $\mathrm{Pt}$ wire counter electrode, $\mathrm{Ag} / \mathrm{AgCl}$ reference electrode. 

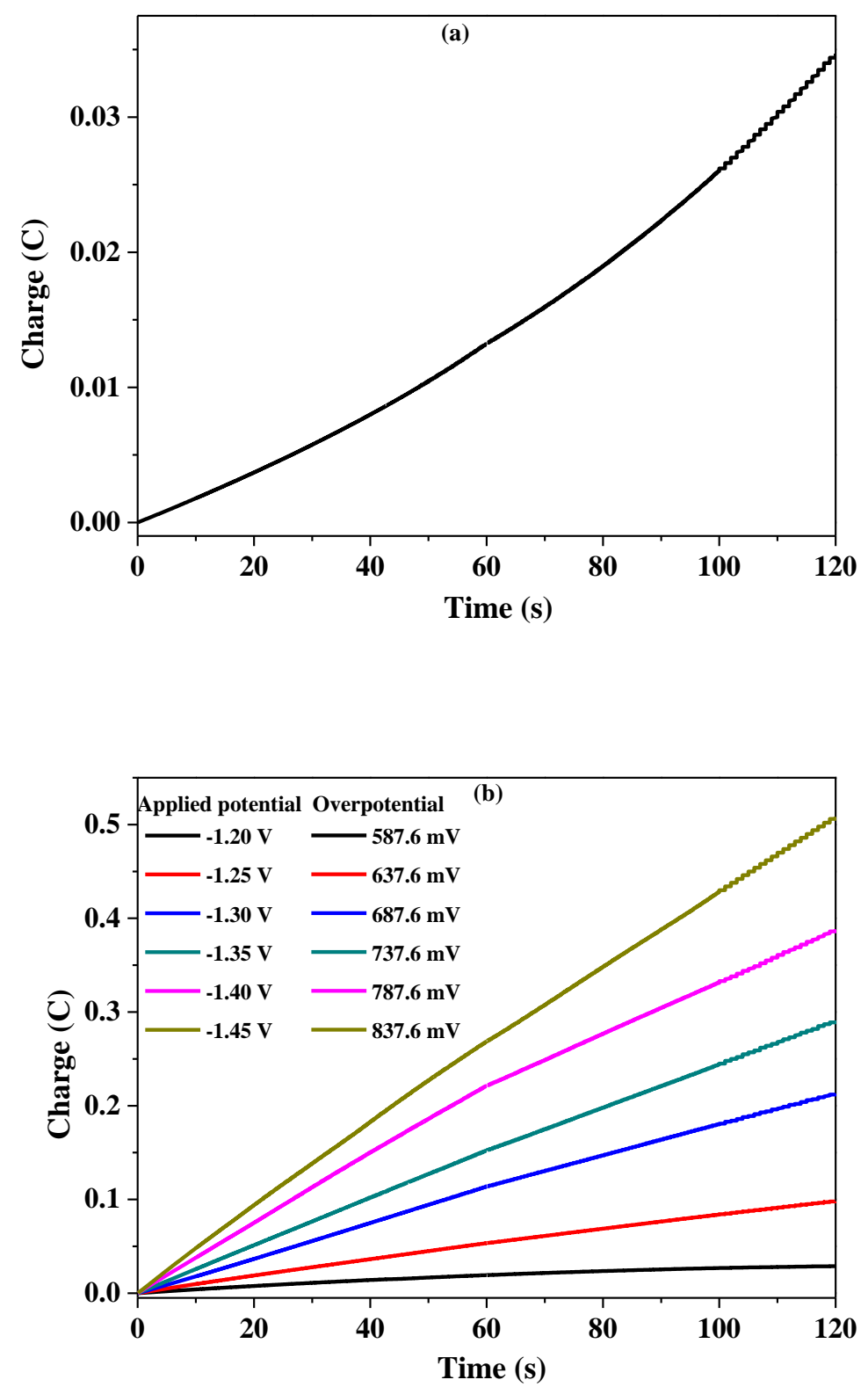


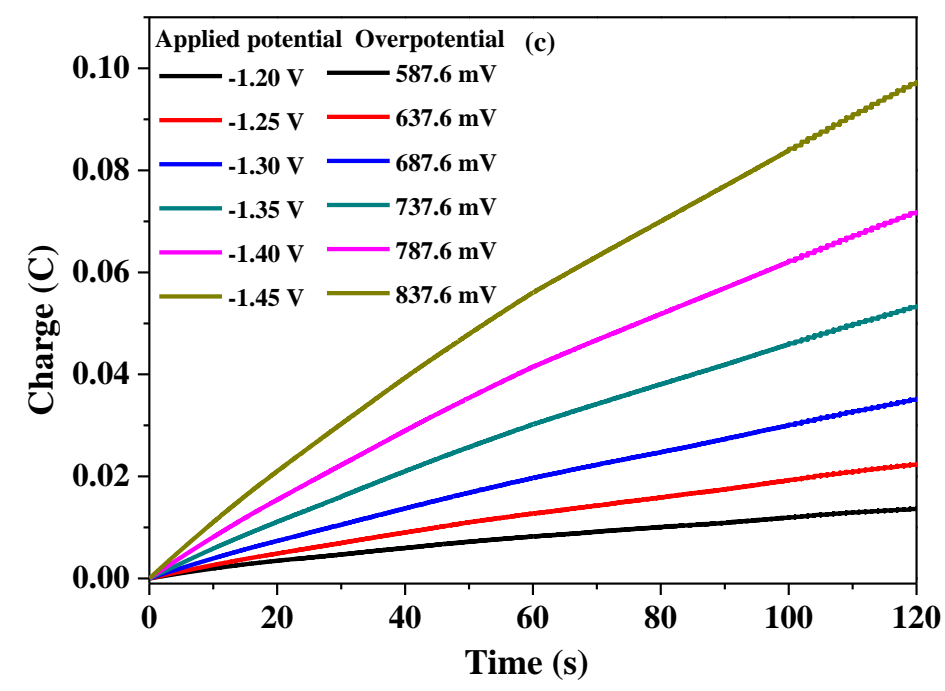

Fig. 6. (a) Charge buildup versus time from electrolysis of a $0.25 \mathrm{M}$ buffer solution (pH 7.0). (b) Charge buildup versus time from electrolysis of $3.09 \mu \mathrm{M}$ complex 1 in a $0.25 \mathrm{M}$ buffer $(\mathrm{pH}$ 7.0) under a series of applied potentials, all data have been deducted blank. (c) Charge buildup versus time from electrolysis of $2.28 \mu \mathrm{M}$ complex 2 in a $0.25 \mathrm{M}$ buffer ( $\mathrm{pH}$ 7.0) under a series of applied potentials, all data have been deducted blank. 